\title{
Performance of intercropping in pre-bearing mango orchards under drip irrigation in a degraded land
}

\author{
S. Pradhan* \\ ICAR-Indian Institute of Water Management, Bhubaneswar-751023, India \\ P. Sahu \\ ICAR-Indian Institute of Water Management, Bhubaneswar-751023, India \\ P. Panigrahi \\ ICAR-Indian Institute of Water Management, Bhubaneswar-751023, India \\ K.G. Mandal \\ ICAR-Indian Institute of Water Management, Bhubaneswar-751023, India \\ S. K. Ambast \\ ICAR-Indian Institute of Water Management, Bhubaneswar-751023, India
}

${ }^{*}$ Corresponding author. E-mail: sanatan28@gmail.com

\begin{abstract}
A field experiment was carried out to evaluate the performance of pre-bearing mango plantation with different intercrops (papaya, pineapple and combination of papaya and pineapple) in a sandy clay loam soil on a degraded land under drip irrigation at ICARIndian Institute of Water Management, Bhubaneswar, Odisha during 2017-18. Different intercrops planted in the mango (cv. Amrapali) were (i) two rows of papaya (cv. Red lady) in either side of mango plants, (ii) two paired rows of pineapple (cv. Queen) in either side of mango plants and (iii) one row of papaya and one paired row of pineapple in either side of mango plants with and without paddy straw mulch. All plants were irrigated by drip irrigation (DI) system. The amount of water used in mango-papaya cropping system $(1220 \mathrm{~mm})$ was higher than that in mango-pineapple cropping $(975 \mathrm{~mm})$. The volumetric soil water content in top $0.60 \mathrm{~m}$ soil in mango, papaya and pineapple were $20-23 \%$, 21$24 \%$ and $22-24 \%$, respectively. The vegetative growth parameters (plant height, canopy diameter and trunk girth) of young mango plants were not affected significantly either by papaya or pineapple intercropping. Straw mulch enhanced the growth parameters of mango plants by $8-12 \%$. Similarly, growth parameters of papaya and pineapple were not affected significantly either by intercrops or by straw mulch. The highest yield (17.5 t/ha) and water productivity $(21.1 \mathrm{~kg} / \mathrm{ha} . \mathrm{mm})$ were observed in mango-pineapple system with straw much. The net profit from pineapple intercropping with straw mulch was highest (Rs. $140000 /$ ha) with benefit-cost ratio of 1.67 , followed by papaya-pineapple intercropping with straw mulch in mango. Overall, the study reveals that mango intercropped with pineapple under drip irrigation with rice straw mulch can be practiced in pre-bearing mango orchards of Eastern India.
\end{abstract}

Keywords: Drip irrigation, Intercropping, Pre-bearing mango, Water productivity, Yield

\section{INTRODUCTION}

Long juvenile period i.e. duration between planting to fruiting is one of the major constraints in fruit production by small and medium farmers. However, due to higher profit and favourable agro -climates, the area under fruit crops has been increased from 4.01 million hectares in 2001-02 to 6.08 million hectares in 2016-17. Mango is the most important and widely grown tropical fruit crop of India, covering an area of 2.26 million hectares with an annual production of 19.68 million tonnes (Gol, 2017). Eastern India is one of the potential zones for mango cultivation with at least

\section{Article Info}

DOI:10.31018/jans.v10i4.1828

Received: July 12, 2018

Revised: September 19, 2018

Accepted: October 9, 2018

\section{How to Cite}

Pradhan, S. et al. (2018).

Performance of intercropping in pre-bearing mango orchards under drip irrigation in a degraded land. Journal of Applied and Natural Science, 10(4): $1124-1129$
3-4 years of juvenile period (Swain, 2014). The orchard growers pay substantial amount of interest on the financial investment in establishing and maintenance of orchards in the region. In this scenario, growing of suitable intercrops in mango orchards in initial periods of plantation are utmost essential.

Intercropping in mango orchards was earlier studied by different researchers. Rajput et al. (1989) has advocated intercrops in mango orchard during pre-bearing stage in order to get additional income. Singh et al. (2012) studied the effect of intercrops like cowpea, french bean, arhar, soy- 
bean, lentil, chick pea and black gram in mango and observed higher mango yield in mangocowpea system followed by mango-lentil system and least in sole crop. Swain (2014) studied the effect of intercrops (mango ginger, turmeric, cow pea, tomato, french bean, ragi, niger, upland paddy) in eastern ghat high land zone of Odisha on mango performance and observed that the mango -guava-cowpea intercropping system exhibited better performance in relation to vegetative growth and fruit yield, closely followed by mango-guavafrench bean system. Similarly, Sarkar et al. (2004), Ratha and Swain (2006), Raut et al. (2006), Jain et al. (2006), Tiwari and Baghel (2014) has also reported the beneficial or nondetrimental effect of intercrops on mango plants. Overall, it was observed that the fruit yield of mango with leguminous intercrops like cowpea, lentil, frenchbean etc. was higher than that without intercrops. The higher yield of the mango with leguminous intercrops was due to improved availability of soil nutrients probably caused by nitrogen fixation from air to soil by intercrops, reduction in soil and nutrients erosion from orchard floor due to obstruction created by intercrops, application of fertilizers for intercrops, and incorporation and decomposition of intercrop residues in soil of the orchard. In other hand, the non-leguminous intercrops benefitted the main crop through creating a better micro-climate that might help in improving fruit yield of mango.

As an evergreen tree crop, mango requires 1200$1400 \mathrm{~mm}$ water in a year (Carr, 2014). The higher variation of rainfall in space and time in a year creates water scarcity which causes drastic yield reduction in the crop (Panigrahi et al., 2011). Moreover, the intercrops start competing with the main fruit trees for nutrients and water resulting lower orchard efficiency. Therefore, planning of inter crops in mango orchards should be based on judicious use of land, water, nutrients and solar energy available with better financial return from the orchard.

Drip irrigation (DI) has been found as a potential water saving technique in fruit cultivation (Panigrahi et al. 2012). However, the use of DI increases the investment in young pre-bearing orchards. The cultivation of high value fruit crops with short duration juvenile period as inter crops is one of the options to generate more profits with compensating the investment in $\mathrm{DI}$ in pre-bearing orchards. Very limited information is available on the performance of high value and short duration fruit crops like papaya and pineapple as inter crops in pre-bearing mango orchards under drip irrigation. Moreover, the information in a degraded land is lacking. Keeping these in view, the present experiment was undertaken to study the performance of pre-bearing mango orchard with papaya and pineapple inter-crops under DI in a degraded land of eastern India.

\section{MATERIALS AND METHODS}

The experiment was conducted in a pre-bearing mango (cv. Amrapalli) orchard in a degraded land at ICAR-Indian Institute of Water Management (20.3148 $\mathrm{N}$ latitude, $85.8106^{\circ} \mathrm{E}$ longitude and 48 $\mathrm{m}$ above mean sea level), Bhubaneswar, Odisha state, India during 2017-18. The intercrops taken for the study were papaya (cv. Red lady), pineapple (cv. Queen) and combination of papaya and pineapple in the mango orchard. Papaya and pineapple were planted with the spacing of $2.0 \mathrm{~m}$ $\times 2.0 \mathrm{~m}$ and $0.45 \mathrm{~m} \times 0.60 \mathrm{~m}$, respectively, in the mango plantation with $6 \mathrm{~m} \times 6 \mathrm{~m}$ spacing. The soil type of the experimental site was sandy loam with bulk density of $1.55 \mathrm{~g} \mathrm{~cm}^{-3}$ and $\mathrm{pH}$ of 6.7 . The organic carbon of the soil was $0.32 \%$. The average rainfall at the site is around $1500 \mathrm{~mm}$, out of which more than $80 \%$ is confined in monsoon season (June-September) of a year.

Different intercrops planted in the mango orchard were (i) two rows of papaya in either side of mango plants with and without paddy straw mulch, (ii) two paired rows of pineapple in either side of mango plants with and without paddy straw mulch and (iii) one row of papaya and one paired row of pineapple in either side of mango plants with and without paddy straw mulch using randomized block design with three replicates. The details of treatments are presented in Table-1.

Water supply was done to each crop through DI. On-line drip irrigation (16 $\mathrm{mm}$ lateral pipe and 4 liters per hour emitters) was used for mango and papaya, whereas in-line drip (16 $\mathrm{mm}$ lateral pipe and 2.6 liters per hour emitters) was used for pineapple. The hydraulic parameters (Distribution Uniformity, Co-efficient of Variation) of the drip system, as estimated following standard procedure (Michael, 1993) were found satisfactory for irrigation. The irrigation scheduling to each crop was done on daily basis based on the crop water requirement of the crops, estimated using the procedure suggested by Doorenbos and Pruit (1984).

The recommended package and practices were followed for main crop mango and intercrops papaya and pineapple. The main crop mango was fertilized with $15 \mathrm{~kg}$ of FYM, $300 \mathrm{~g} \mathrm{~N}, 150 \mathrm{~g} \mathrm{P}_{2} \mathrm{O}_{5}$ and $300 \mathrm{~g}$ of $\mathrm{K}_{2} \mathrm{O}$ per plant per year. Entire dose of FYM and half dose of N, P and $K$ should be given during monsoon (June/July) while the balance half is applied during the end of monsoon (October). The intercrop pineapple was fertilized with $12 \mathrm{~g} \mathrm{~N}, 4 \mathrm{~g}$ of $\mathrm{P}_{2} \mathrm{O}_{5}$ and $12 \mathrm{~g}$ of $\mathrm{K}_{2} \mathrm{O}$ per plant per year. Pineapple plants were also supplied with FYM @10 t/ha. N was applied in 6 split doses. The first dose of $\mathrm{N}$ was given two months after planting and the last one 12 months after planting. Entire $P$ and half of $K$ were given at the time of planting and the remaining $\mathrm{K}, 6$ months after 
planting. The intercrop papaya was fertilized with $20 \mathrm{~kg}$ FYM, $250 \mathrm{~g} \mathrm{~N}, 250 \mathrm{~g} \mathrm{P}_{2} \mathrm{O}_{5}$ and $250 \mathrm{~g} \mathrm{~K}_{2} \mathrm{O}$ per plant per year. The fertilizer were applied in two splits; the first in the beginning of monsoon and second in the later part. Weeding and intercultural operations were practiced as per the requirement.

The soil water content up to the depth of $60 \mathrm{~cm}$ was measured using gravimetric method. The biometric observations for mango, pineapple and papaya were recorded once in three months. The yield of papaya and pineapple were recorded by harvesting total yield from the treatments. The water productivity was estimated as yield per unit quantity of water used in total cropping sequence including mango. The total soluble solids were found out by using refractometer. The acidity of the fruit pulp samples were estimated by alkali titration method. The economics of production was worked out following the formula by Reddy and Ram (1996). The growth, yield and quality parameters recorded were statistically analyzed using analysis of variance (ANOVA) as applicable to randomized block design (Gomez and Gomez, 1984). The significance of the treatment effects was determined using F-test, and the difference between the means was estimated using least significance difference at $5 \%$ probability level.

\section{RESULTS AND DISCUSSION}

Soil water dynamics: The soil water dynamics of surface $60 \mathrm{~cm}$ soil depth under different crops are presented in Fig. 1. The soil water content in the profile progressively decreased from April (22.2 $\left.\mathrm{cm}^{3} / \mathrm{cm}^{3}\right)$ to June $\left(21.4 \mathrm{~cm}^{3} / \mathrm{cm}^{3}\right)$ and from December $\left(23.7 \mathrm{~cm}^{3} / \mathrm{cm}^{3}\right)$ to March $\left(22.5 \mathrm{~cm}^{3} / \mathrm{cm}^{3}\right)$. However, the soil water did not attend $50 \%$ allowable soil moisture depletion in any crop. The soil water content in root zone of pineapple plants (22 $-24.1 \mathrm{~cm}^{3} / \mathrm{cm}^{3}$ ) was higher than that in papaya $\left(21.9-23.9 \mathrm{~cm}^{3} / \mathrm{cm}^{3}\right)$ and mango plants $(21-23.8$ $\mathrm{cm}^{3} / \mathrm{cm}^{3}$ ). Among the three crops, pineapple stored more soil water compared to the other

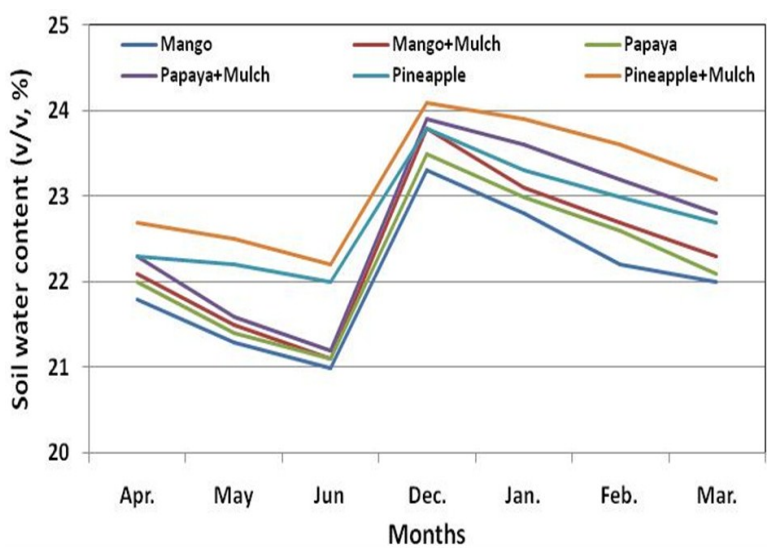

Fig. 1. Soil water content at $60 \mathrm{~cm}$ soil depth in various crops. crops, but they were not statistically significant. Vegetative growth parameters of mango, papaya and pineapple: The vegetative growth parameters of mango, papaya and pineapple are presented in Table 2. The highest plant height $(3.06 \mathrm{~m})$, canopy diameter $(3.25 \mathrm{~m})$ and trunk girth $(29.3 \mathrm{~cm})$ of mango was observed in mango with mulch treatment. The lowest plant height $(2.50 \mathrm{~m})$, canopy diameter $(2.37 \mathrm{~m})$ and trunk girth $(26.2 \mathrm{~cm})$ of mango plants was observed in mango+papaya+pineapple without mulch treatment. However, the vegetative growth parameters of mango were not affected significantly by either intercrops or mulch, as evident from nonsignificant values of Critical difference (CD) estimated from statistical analysis of data (Table-2). Tiwari and Baghel (2014) also didn't observe any significant effect of various mono, companion and sequential inter-croppings on main crop mango.

The highest papaya plant height $(1.47 \mathrm{~m})$, canopy diameter $(1.44 \mathrm{~m})$ and fruit set no. (12) were observed in mango+papaya with mulch treatment. The lowest papaya plant height $(1.34 \mathrm{~m})$, canopy diameter $(1.22 \mathrm{~m})$ and fruit set no. (7) was observed in mango+papaya+pineapple without mulch treatment. Similar to the growth parameters of mango, the growth parameters of papaya were not significantly affected in mango based intercroppings. The highest shrub height $(34.8 \mathrm{~cm})$, number of leaves (35) and number of suckers/slips (6) of pineapple was observed in mango+pineapple with straw mulch. The lowest shrub height $(31.6 \mathrm{~cm})$, no. of leaves (30) and no. of suckers/slips (4) was of pineapple was observed in mango+papaya+pineapple without straw mulch. Similar to papaya, the pineapple growth parameters were not significantly affected by the mango based inter-croppings. Raut and Jain (2013) also didn't observe any significant variation in plant height and girth of filler crop (pomegranate) influenced by intercrops in mango orchard. It may be attributed to the nonexistence of competition for light, water and nutrient between the base crop mango and intercrops (Swain, 2014).

Water used, yield/Pine apple equivalent yield (PEY) and water productivity (WP) of mango based inter-cropping: The amounts of water used by the crops involved in different intercropping systems during April 2017-March 2018 are presented in Table 3 . The water use of mango, papaya and pineapple were $650 \mathrm{~mm}, 570 \mathrm{~mm}$ and $325 \mathrm{~mm}$, respectively. The mango+ papaya+ pineapple system without straw mulch had highest (1545 mm) water use followed by mango+papaya+ pineapple system with straw mulch $(1360 \mathrm{~mm})$ and the least in sole mango with straw mulch (572 $\mathrm{mm})$. Straw mulching reduced water use by $12-$ $15 \%$ under different mango based inter-croppings. The reduction of water use under straw mulch was due to reduction in evaporation from soil surface 
Table 1. Treatment details of intercrops in mango.

\begin{tabular}{llll}
\hline Treatments & Details & Treatments & Details \\
\hline $\mathrm{T}_{1}$ & Mango+ Papaya+ Pineapple & $\mathrm{T}_{5}$ & Mango+ Pineapple+ SM \\
$\mathrm{T}_{2}$ & Mango+ Pineapple & $\mathrm{T}_{6}$ & Mango+ papaya + SM \\
$\mathrm{T}_{3}$ & Mango+ papaya & $\mathrm{T}_{7}$ & Mango + SM \\
$\mathrm{T}_{4}$ & Mango+ Papaya+ Pineapple+SM & $\mathrm{T}_{8}$ & Mango \\
\hline
\end{tabular}

*SM: Straw mulch

Table 2. Vegetative growth parameters of mango, papaya and pineapple intercropped in mango.

\begin{tabular}{|c|c|c|c|c|c|c|c|c|c|}
\hline \multirow[b]{2}{*}{$\begin{array}{l}\text { Treat- } \\
\text { ments }\end{array}$} & \multicolumn{3}{|l|}{ Mango } & \multicolumn{3}{|l|}{ Papaya } & \multicolumn{3}{|c|}{ Pineapple } \\
\hline & $\begin{array}{l}\text { Plant } \\
\text { height } \\
\text { (m) }\end{array}$ & $\begin{array}{l}\text { Canopy } \\
\text { diameter } \\
\text { (m) }\end{array}$ & $\begin{array}{l}\text { Trunk girth } \\
\text { (cm) }\end{array}$ & $\begin{array}{l}\text { Plant } \\
\text { height ( } m)\end{array}$ & $\begin{array}{l}\text { Canopy } \\
\text { diameter } \\
\text { (m) }\end{array}$ & $\begin{array}{l}\text { Fruit } \\
\text { set } \\
\text { (No.) }\end{array}$ & $\begin{array}{l}\text { Shrub } \\
\text { height } \\
\text { (cm) }\end{array}$ & $\begin{array}{l}\text { No. of } \\
\text { leaves }\end{array}$ & $\begin{array}{l}\text { No. of } \\
\text { Suckers/ } \\
\text { slips }\end{array}$ \\
\hline$T_{1}$ & 2.50 & 2.37 & 26.2 & 1.34 & 1.22 & 7 & 31.6 & 30 & 4 \\
\hline $\mathrm{T}_{2}$ & 2.67 & 2.85 & 28.4 & - & - & - & 34.8 & 33 & 5 \\
\hline $\mathrm{T}_{3}$ & 2.52 & 2.48 & 28.0 & 1.42 & 1.28 & 10 & - & - & - \\
\hline $\mathrm{T}_{4}$ & 2.64 & 2.54 & 27.4 & 1.46 & 1.35 & 9 & 33.5 & 32 & 5 \\
\hline$T_{5}$ & 2.80 & 3.01 & 28.8 & - & - & - & 34.8 & 35 & 6 \\
\hline $\mathrm{T}_{6}$ & 2.72 & 2.66 & 28.5 & 1.47 & 1.44 & 12 & - & - & - \\
\hline $\mathrm{T}_{7}$ & 3.06 & 3.25 & 29.3 & - & - & - & - & - & - \\
\hline $\mathrm{T}_{8}$ & 2.92 & 3.14 & 29.0 & - & - & - & - & - & - \\
\hline$C D_{0.05}$ & $N S^{*}$ & NS & NS & NS & NS & NS & NS & NS & NS \\
\hline
\end{tabular}

${ }^{*} \mathrm{NS}$ : non-significant

Table 3. Water used, yield/PEY and water productivity (WP) of mango based intercropping.

\begin{tabular}{lccc}
\hline Treatments & Water used $\mathbf{( m m )}$ & Yield/PEY (t/ha) & WP (kg/ha/mm) \\
\hline $\mathrm{T}_{1}$ & 1545 & 11.24 & 7.27 \\
$\mathrm{~T}_{2}$ & 975 & 17.14 & 17.58 \\
$\mathrm{~T}_{3}$ & 1220 & 5.34 & 4.38 \\
$\mathrm{~T}_{4}$ & 1360 & 11.37 & 8.36 \\
$\mathrm{~T}_{5}$ & 828 & 17.48 & 21.11 \\
$\mathrm{~T}_{6}$ & 1075 & 5.43 & 5.05 \\
$\mathrm{~T}_{7}$ & 572 & - & - \\
$\mathrm{T}_{8}$ & 650 & - & - \\
$\mathrm{CD}(0.05)$ & $\mathrm{NS}$ & 1.08 & 0.86 \\
\hline
\end{tabular}

PEY: Pineapple equivalent yield; WP: Water productivity; NS: non-significant

Table 4. Fruit quality of papaya and pineapple under different intercropping.

\begin{tabular}{lccc}
\hline Treatments & TSS $\left(^{\circ}{ }^{\circ} \mathbf{B r i x}\right)^{*}$ & Acidity (\%) & Ascorbic acid $(\mathbf{m g} / \mathbf{1 0 0} \mathbf{g})$ \\
\hline $\mathrm{T}_{1}$ & $9.6(15.7)$ & $0.16(0.61)$ & $50.21(21.5)$ \\
$\mathrm{T}_{2}$ & 15.3 & 0.66 & 22.3 \\
$\mathrm{~T}_{3}$ & 9.4 & 0.18 & 49.96 \\
$\mathrm{~T}_{4}$ & $9.8(16.03)$ & $0.15(0.57)$ & $51.03(22.0)$ \\
$\mathrm{T}_{5}$ & 16.00 & 0.59 & 22.7 \\
$\mathrm{~T}_{6}$ & 9.5 & 0.15 & 50.76 \\
$\mathrm{~T}_{7}$ & - & - & - \\
$\mathrm{T}_{8}$ & - & - & - \\
$\mathrm{CD}(0.05)$ & $\mathrm{NS}$ & $\mathrm{NS}$ & $\mathrm{NS}$ \\
\hline
\end{tabular}

* Values in parenthesis is for pineapple

Table 5. Economics of production under different inter-cropping systems with drip irrigation and straw mulch in pre-bearing mango orchard.

\begin{tabular}{lcccc}
\hline Treatments & Gross investment (Rs/ha) & Gross return (Rs/ha) & Net return (Rs/ha) & Benefit-cost ratio \\
\hline $\mathrm{T}_{1}$ & 208000 & 224800 & 16800 & 1.08 \\
$\mathrm{~T}_{2}$ & 208000 & 342800 & 134800 & 1.64 \\
$\mathrm{~T}_{3}$ & 150000 & 106800 & -43200 & 0.71 \\
$\mathrm{~T}_{4}$ & 169000 & 227400 & 58400 & 1.34 \\
$\mathrm{~T}_{5}$ & 209600 & 349600 & 140000 & 1.67 \\
$\mathrm{~T}_{6}$ & 151600 & 108600 & -43000 & 0.71 \\
$\mathrm{~T}_{7}$ & 118000 & 0 & -118000 & --- \\
$\mathrm{T}_{8}$ & 116400 & 0 & -116400 & --- \\
\hline
\end{tabular}


under mulch (Panigrahi et al., 2010).

The yield or pineapple equivalent yield (PEY) of different mango based inter-croppings ise presented in Table 3. The mango+pineapple system with straw mulch gave significantly $(P<0.05)$ higher PEY (17.48 t/ha) compared to other systems followed by mango+pineapple system without straw mulch (17.14 t/ha). However, the PEY of mango+pineapple system without straw mulch was statistically at par with the mango+pineapple system with straw mulch. The mango+papaya system without straw mulch gave significantly lower (5.34 t/ha) PEY. However, the PEY of mango+papaya system without straw mulch was statistically at par with the mango+papaya system with straw mulch. The mango+pineapple system registered up to $66 \%$ and $227 \%$ higher PEY compared to mango+pineapple+papaya and mango+papaya intercropping system, respectively. Earlier studies by Tiwari and Baghel (2014); Swain (2014), Swain et al., (2016) and Ghosh et al. (2017) had also reported that intercropping in widely spaced fruit crops resulted higher system equivalent yield compared to the sole crop (Tiwari and Baghel, 2014; Swain, 2014, Swain, 2016 and Ghosh et al., 2017).

The water productivity of mango based intercroppings are presented in Table-3. The mango+pineapple system with mulch had highest $(P \leq 0.05)$ water productivity $(21.11 \mathrm{~kg} / \mathrm{ha} . \mathrm{mm})$ compared to the other systems under study (4.38 $-17.58 \mathrm{~kg} / \mathrm{ha} . \mathrm{mm})$. However, straw mulching did not affect significantly water productivity of mango+papaya system. The straw mulching increased water productivity by $15-20 \%$ compared to no straw mulching in the mango based intercroppings.

Quality parameter of papaya and pineapple: The fruit quality (TSS, acidity and ascorbic acid) parameters of the intercrops papaya and pineapple are presented in Table 4. The TSS varied from 9.4 to $9.8^{\circ}$ Brix and 15.3 to $16.03^{\circ}$ Brix in papaya and pineapple, respectively. The fruit acidity varied from 0.15 to $0.18 \%$ in papaya and 0.57 to $0.66 \%$ in pineapple. Similarly, the ascorbic acid ranged between 49.96 to $51.03 \mathrm{mg} / 100 \mathrm{~g}$ of pulp in papaya and 21.5 to $22.7 \mathrm{mg} / 100 \mathrm{~g}$ of pulp in pineapple. However, the fruit quality of papaya and pineapple were not affected significantly in the mango based intercropping.

Economics: The economics of production under different inter-cropping systems in mango orchard is presented in Table-5. In spite of higher production cost/investment (Rs. 209600/ha), the maximum net return (Rs. 140000/ha) was generated under pineapple intercropping with straw mulch in mango orchard, due to higher return from pineapple. The benefit-cost ratio was also higher in pineapple with straw mulch (1.67) compared with other intercrops under DI in mango. However, inter- cropping of papaya with or without straw mulch was not found economically suitable due to less return than production cost in the crop in mango orchard.

\section{Conclusion}

The performance evaluation of pre-bearing mango orchard with different intercrops (papaya, pineapple and combination of papaya and pineapple) under drip irrigation and paddy straw mulch was studied in a sandy clay loam soil. The mangopineapple cropping with straw mulch produced the highest yield/ pineapple equivalent yield (17.5 t/ ha) and water productivity (21.1 kg/ha.mm), using least amount of water $(975 \mathrm{~mm})$ among the intercropping systems. Moreover, the cropping generated the highest net profit (Rs. 140000/ ha) with benefit-cost ratio of 1.67 . Thus, mango intercropped with pineapple under drip irrigation and straw mulch may be demonstrated/ adopted in large scale to generate more profits in early years of mango orchards in water scarce regions of eastern India.

\section{REFERENCES}

1. Carr, M.K.V. (2014). The water relations and irrigation requirements of mango (Mangifera indica L.): a review. Experimental Agriculture, 50 (1): 1-23.

2. Doorenbos, J. and Pruit, W. O. (1984). Guidelines for predicting crop water requirements. FAO Irrigation and Drainage paper 24, FAO, Rome, $144 \mathrm{pp}$.

3. Ghosh, S., Sarkar, S., Sau, S., Karmakar, and Brahmachari, K. (2017). Influence of Guava (Psidium guajava L.) based Intercropping Systems on Soil Health and Productivity in Alluvial Soil of West Bengal, India. International Journal of Current Microbiology and Applied Sciences. 6(11): 241-251.

4. Gomez, K.A., Gomez, A.A., 1984. Statistical Procedures for Agricultural Research, $2^{\text {nd }}$ Edition, Wiley, New York.

5. Jain, P.K., Raut, R.L. and Rajwade, V.B. (2008). Mango based intercropping under the watershed of Kymore plateau of Madhya Pradesh. Indian Journal of Horticulture, 65: 486-487.

6. Michael, A. M. (1993). Irrigation- Theory and Practice, Vikas Publishing House Pvt. Ltd., New Delhi, $787 \mathrm{pp}$.

7. Panigrahi, P., Srivastava, A. K. and Huchche, A. D. (2010). Optimizing growth, yield and water use efficiency (WUE) in Nagpur mandarin (Citrus reticulata) under drip irrigation and plastic mulch. Indian Journal of Soil Conservation, 38 (1): 42-45.

8. Panigrahi, P., Sahu, N. N. and Pradhan, S. (2011) Evaluating partial root-zone irrigation and mulching in okra (Abelmoschus esculentus L.) under a sub-humid tropical climate. Journal of Agriculture and Rural Development in the Tropics and Subtropics, 112 (2): 169-175.

9. Panigrahi, P., Srivastava, A. K., Huchche, A. D. and Singh, S. (2012). Plant nutrition in response to drip versus basin irrigation in young Nagpur mandarin on Inceptisol. Journal of Plant Nutrition, 35: 215-224.

10.Rajput M.S., Shrivastava K.C., and Shukla V. (1989) Intercropping in young mango orchard, Acta Horticul- 
ture. 231: 312-315

11.Ratha, S. and Swain, S.C. (2006). Performance of intercrops in mango orchard in Eastern Ghat High Land Zone of Orissa. Indian Journal of Dryland Agricultural Research Development. 21:12-15.

12.Raut, R. L. (2006). Performance of various intercrops in relation to land equivalent ratio (LER) and their influence on yield attributes and yield of mango (Mangifera indica L.). Journal of Soils and Crops. 16: 295-299.

13.Raut, R.L. and Jain, P.K. (2013). Intercropping systems in mango orchard for rainfed area of central India. International Journal of Horticulture,3(15):8790

14.Reddy, S. S. and Ram, P.R. (1996). Agricultural Finance and Management, $2^{\text {nd }}$ edn. Oxford and IBH Publisher Co. Pvt. Ltd., New Delhi

15.Sarkar, S.K., Gautam, B., Seethambram, Y. and Vijaya, N. (2004). Effect of intercropping sequence with vegetables in young mango orchard under
Decan plateau. Indian Journal of Horticulture, 61: 125 $-127$

16.Singh. S.R., Banik, B.C. and Yumnam, S.S. (2012) Effect of different intercrops on yield and quality of mango production in new alluvial zone of West Bengal. The Asian Journal of Horticulture. 7(2): 582-585.

17.Swain, S.C. (2014). Performance and profitability study of different mango based intercropping systems in Easternghat high land zone. Journal of Crop and Weed. 10(2): 170-178.

18.Swain, S.C. (2016). Influence of intercropping systems on soil health, productivity and quality of guava (Psidium guajava I.) in Eastern India. Journal of Plant Nutrition. 39(14): 2037-2046.

19. Tiwari, R. and Baghel, B.S. (2014). Effect of intercropping on plant and soil of Dashehari mango orchard under low productive environments. The Asian Journal of Horticulture. 9(2): 439-442. 